\title{
Soft Budget Constraints and Investment Support in Estonian Agriculture
}

\author{
Olga Aleksandrova \\ Donbas National Academy of Civil Engineering and Architecture, \\ 2, Derzhavina str., Makeyevka, 286123, Ukraine. \\ E-mail: alexand_olga_la@mail.ru
}

\begin{abstract}
The article discusses the question of the financial constraints in Estonian dairy and crop farms in the transition period, and there are also identified the farms that have been mostly affected by these imperfections. For that, an investment accelerator model augmented with a cash flow variable was used. The empirical analysis is based on the unbalanced panel data containing 2263 dairy and 1762 crop farms in the period between 2000 and 2014. We have three periods of 5 years each: 2000-2004 (the pre-EU accession), 2005-2009 (being an EU member before the economic crisis), 2010-2014 (after the economic crisis). We used these periods to construct the fixed effect and random effect models for different types of farm: dairy and crop farms. In addition to the full sample estimate, we use farms characteristics to classify crop farms by area, and dairy farms by the average number of cows per year. The estimations of the standard augmented model obtained by different econometric methods for several sub-samples have revealed a dissimilar level of the financial constraints. The obtained results clearly imply that the farm investment behavior is driven by the competitive output market conditions and the farm abilities to sell output and invest in such a market environment. Moreover, except for all farms farm the gross investment is positively and significantly associated with the cash flow, confirming for any farms the absence of the soft budget constraints for the farms. The results confirm that the financial variables significantly influence the farms' investment subsidy, providing an empirical evidence of an imperfect capital market in the Estonian agriculture.
\end{abstract}

Key words: farms; investment; accelerator model; soft budget constraints; investment subsidy; unbalanced panel data; Estonia.

JEL Classification: C33, E22, G31, Q14.

Olga V. Aleksandrova - Candidate of Physical - Mathematical Sciences (Theory of probability and mathematical statistics). Docent (Associate Professor), Department of Higher Mathematics and Informatics.

The article was received: 12.12.2019/The article is accepted for publication: 05.03.2020. 
DOI: $10.17323 / 1813-8691-2020-24-1-85-100$

For citation: Aleksandrova O.V. Soft Budget Constraints and Investment Support in Estonian Agriculture. HSE Economic Journal. 2020; 24(1): 85-100.

\section{Introduction}

In the 1990s, Estonian agricultural producers lacked means for making investments. Agricultural producer prices were low, credit for agricultural producers was expensive, and agricultural land was not accepted as collateral.

Estonia ratified the Europe Agreement, i.e. accepted the policy, purposes and measures of the European Community, in 1995. The first action plan towards joining the EU was adopted in 1996, pre-accession negotiations began in 1997, and more profound action plan for EU accession was approved in 1998. In 1999, the Phare Special Preparatory Programme was launched, which laid the ground for the implementation of the Special Accession Programme for Agriculture and Rural Development (SAPARD) [Estonian Ministry of Agriculture, 1999]. Supporting the investments of agricultural producers was one of the main aims of these programs, in order to compensate for the «lost decade» of agricultural investments in the 1990-ies.

In transition countries, agricultural producers often face budget constraints that hinder the investment for modernization of the production. In these conditions, the government applies policies that facilitate farm investments.

After the EU accession, Estonia has applied National Development Plan 2004-2006, Estonian Rural Development Programme 2007-2013, and Estonian Rural Development Programme 2014-2020. In these progammes, supporting the investments for modernization of agricultural holdings has had a prominent role.

One of the evaluation questions of Rural Development Programmes is related to the stimulative effect of investment subsidies. If the subsidies do not have stimulating effect on the investments, the government could find more rewarding use for the resource.

After the EU accession, the producer prices for Estonian farmers increased, as well as the direct farm payments, and there were more resources for supporting farm investments. In addition, opportunities for credit have been improved.

Therefore, the question about credit constraints in Estonian agriculture, and stimulating effect of investment subsidies is relevant both, from the historic perspective of Estonia as a transition economy, and from the perspective of Estonia as an EU member state, applying the Common Agricultural Policy, and focusing a lot on investment support in its II pillar.

The paper investigates the role of financial constraints on the investment behavior of Estonian dairy and crop farms between 2000 and 2014. The paper aims to evaluate the existence of soft budget constraints, and the effect of investment support on investments of Estonian agricultural producers. For that, we use Estonian FADN individual data of specialized milk and crop farms from 2000-2014.

The article is organized as follows. Section 2 explains the literature review and theoretical framework of credit market imperfections in different countries with transition, and how to test them with an accelerator model. Section 3 outlines the methodology. Data and descriptive statistics are reported and discussed in Section 4; the results and discussion are presented in Section 5; and some concluding remarks are included in Section 6. 


\section{A Literature Survey}

There are several works studying the behavior of investment in countries with economies in transition. [Lizal, Svejnar, 2002] analyze investment in firms in the Czech Republic in the 1990s, while [Budina et al,. 2000] analyze investment of Bulgarian firms over the period 19931995. [Konings et al., 2003] investigated the extent firm investment in transition countries is sensitive to internal finance. For this they have used a unique panel of manufacturing firms consisting of comparable data for Poland, the Czech Republic, Bulgaria and Romania between 1994 and 1999 to investigate the role of financial constraints on the investment behavior of firms. A few papers focusing on this issue for the agricultural sector in these countries: [Petrick, 2004; Latruffe, 2005; Bojnec, Latruffe, 2007; Bakucs et al., 2009; Latruffe et al., 2010]. This research provides evidence for existence of capital market imperfections during transition and after accession to the European Union (EU) [Rizov et al., 2001]). The article [Bakucs et al., 2011] investigates the investment and financial constraints for French, Hungarian and Slovenian farms using FADN panel data with different econometric estimation approaches. Constraints on the rural credit market seems to be the cause for low farm indebtedness [Latruffe, 2005]. Empirical research provides evidence that supports the notion that corporate balance sheets influence investment spending, though this evidence is more contentious. It is well known that business investment spending is strongly correlated with corporate cash flow [Gilchrist, 2012]. Earlier research by [Fazzari et al., 1988] has established that cash flows stimulate investment due to internal funds are a cheaper source of finance than external funds.

Standard accelerator model assuming perfect capital markets can be applied in order to test for discrepancy between internal and external finance [Fazzari et al., 1988]. However, capital markets in transitional countries are probably more subject to imperfections due to transaction costs and information asymmetries especially for farmers.

\section{Methods}

Our study is to estimate the standard augmented accelerator model which has the following specification:

$$
\frac{I_{i t}}{K_{i t-1}}=\alpha_{i}+\alpha_{1} \frac{Q_{i t}}{K_{i t-1}}+\alpha_{2} \frac{C F_{i t-1}}{K_{i t-1}}+\varepsilon_{i t},
$$

and model with third variables

$$
\frac{I_{i t}}{K_{i t-1}}=\alpha_{i}+\alpha_{1} \frac{Q_{i t}}{K_{i t-1}}+\alpha_{2} \frac{C F_{i t-1}}{K_{i t-1}}+\alpha_{3} \frac{I S_{i t-1}}{K_{i t-1}}+\varepsilon_{i t},
$$

where subscript $i$ denotes the $i$ - th farm and subscript $t$ denotes the $t$ - th period, while $\varepsilon$ is a stochastic element.

$I_{i t}$ denotes gross investment of the $i$ - th farm between periods $t$ and $t-1$, which is calculated as the change in capital stock (net investment) plus depreciation in values; values in period $t$ were deflated by the agricultural input price index change over previous year by goods and services and year; 
$K_{i t-1}$ is the stock of capital, measured by all tangible assets, in the period $t-1$; values in the current period $t$ are deflated by the agricultural input price index;

$Q_{i t}$ is the change in output sales value between period's $\mathrm{t}$ and $t-1$; values in period $t$ were deflated by the agricultural output price index change over previous year by product and year;

$C F_{i t-1}$ is the real cash flow of the $i-$ th farm, defined as before tax profits plus depreciation; values in period $t$ were deflated by the agricultural output price index;

$I S_{i t-1}$ is investment subsidies in $i-$ th farm, defined as before tax profits plus depreciation; values in period $t$ were deflated by the agricultural input price index.

Dependent and explanatory variables are normalized by the stock of capital in time $t-1$ to control for size effects.

The positive regression coefficient $\alpha_{2}$ on the cash-flow variable is generally interpreted as a sign for credit rationing, as proposed by [Fazzari et al., 1988]. Further, Lizal and Svejnar (2002) suggested viewing the coefficient $\alpha_{2}$ as an indication of the presence of the soft budget constraint. They are proposed two versions of the soft budget constraint hypothesis:

$$
\left\{\begin{array}{l}
\alpha_{2}=0-\text { weak version, } \\
\alpha_{2}<0-\text { strong version }
\end{array}\right.
$$

Weak version of the soft budget constraint suggests the farms to have access to credit for investment irrespective of their profitability.

Strong version of the soft budget constraint - that farms with poor financial performance can access bank loans more easily [Lizal, Svejnar, 2002].

In the econometric analysis we use two econometric estimators: random effects (RE), model and fixed effects (FE) model. We employ standard static panel model using the Hausman test to identify whether a RE or FE model is appropriate.

Following [Konings et al., 2003] we estimate Eq. (1) and Eq. (2) in first differences to control for unobserved farm level fixed effect and possible measurement error:

$$
\begin{aligned}
& \Delta \frac{I_{i t}}{K_{i t-1}}=\alpha_{1} \Delta \frac{Q_{i t}}{K_{i t-1}}+\alpha_{2} \Delta \frac{C F_{i t-1}}{K_{i t-1}}+\Delta \varepsilon_{i t}, \\
& \Delta \frac{I_{i t}}{K_{i t-1}}=\alpha_{1} \Delta \frac{Q_{i t}}{K_{i t-1}}+\alpha_{2} \Delta \frac{C F_{i t-1}}{K_{i t-1}}+\alpha_{3} \Delta \frac{I S_{i t-1}}{K_{i t-1}}+\Delta \varepsilon_{i t} .
\end{aligned}
$$

In the empirical analysis we use different econometric estimators. First, we employ standard panel models using the Hausman test to identify whether a random or a fixed effect model is appropriate. Second, we employ the generalized method of moments (GMM) estimator developed by [Arellano, Bond, 1991] to estimate the parameters of equations in first differences. Following [Konings et al., 2003] we will estimate Eq.(3)-(4) with the GMM technique using instrumental variables as it is conceivable that higher investment leads to higher changes in sales and higher cash flows. We also include year dummies to control for unobserved common aggre- 
gate shocks. [Arellano, Bond, 1991] demonstrated that in the first difference model as in Eq. (3)(4) appropriate instruments are the values of the endogenous explanatory variables dated $t-2$ and at earlier dates as they are not correlated with the contemporaneous first differenced error term. As the panel progresses an increasing number of instruments can be used which increases the efficiency of the estimates.

\section{Data and Descriptive Statistics}

The data analysis is based on Estonian Farm Accountancy Data Network (FADN) individual farms database. Our empirical analysis is based of unbalanced panel data containing 2263 dairy and 1762 crop farms.

In our case, we have three periods of 5 years each: 2000-2004 (pre-EU accession), 20052009 (being and EU member before economic crisis), 2010-2014 (after the economic crisis). All the monetary values were adjusted to 2005 prices using price indices of agricultural outputs ( $Q_{i t}$ is the change in output sales value, $C F_{i t-1}$ is the real cash flow) and inputs ( $I_{i t}$ - gross investment, $K_{i t-1}$ - the stock of capital, $I S_{i t-1}$ - investment subsidies in $i$ - th farm).

Moreover, we used these periods for the construction of FE and RE models for different types of farm: dairy and crop farms. We estimated the model (1) and (2) for different types of farms: dairy farms and crop farms. In addition to full sample estimate, we use farms characteristics to classify crop farms by area, and dairy farms by the average number of cows for year.

For crop farms we have 3 groups - divided by square of land ( $S$ is a square of farm land): $S<100$ ha - small farm,

$100 h a \leq S<400 h a$ - middle-sized farm,

$S \geq 400$ ha - large farm.

For milk farm we have also 3 groups:

$N<50$ cows - small farm,

50 cows $\leq N<100$ cows - middle-sized farm,

$N \geq 100$ cows - large farm.

Let us explain how we have calculated the variables $I_{i t}, K_{i t-1}, Q_{i t}, C F_{i t-1}, I S_{i t-1}$.

To calculate of $I_{i t}$ we used the sheet in FADN (investments) and found the sum of the responsible number of column «total investment» and «total amortization».

To calculate of $K_{i t-1}$ the sheet «total assets» and column «total value end of the year» were taken.

To calculate of $Q_{i t}$ we used the sheet in FADN (sales revenue) and found the sum of the responsible number of column from «value of sold wheat» to «compensation for damage caused by nature».

To calculate of $C F_{i t-1}$ the sum values of columns «SE 420 entrepreneurial income» and «total amortization» were taken.

To calculate of $I S_{i t-1}$ we used the sheet «subsidies on investments» and sum values were taken. 
Table 1 presents descriptive statistics of the used data.

Gross investment to capital is on average similar for crop farms and dairy farms. Sale growth to capital is similar for crop farms and dairy farms. Cash flow to capital and real investment subsidy in period $t$ are similar for both types of farms. Real cash flow to capital varies from negative to positive values.

Table 1.

Descriptive statistics for all farms (period 2000-2014)

\begin{tabular}{|c|c|c|c|c|c|c|c|}
\hline Variable & & & Observation & Mean & Std. Dev. & Min & Max \\
\hline \multirow{2}{*}{$\begin{array}{l}\text { Investment } \\
\text { to capital }\end{array}$} & $I_{i t}$ & Dairy & 2263 & 0,1585 & 0,301 & 0 & 4,544 \\
\hline & $\overline{K_{i t-1}}$ & Crop & 1762 & 0,191 & 0,324 & 0 & 3,045 \\
\hline \multirow{2}{*}{$\begin{array}{l}\text { Sale growth } \\
\text { to capital }\end{array}$} & $Q_{i t}$ & Dairy & 2263 & 0,441 & 0,314 & 0,002 & 3,253 \\
\hline & $\overline{K_{i t-1}}$ & Crop & 1762 & 0,412 & 0,314 & 0,0002 & 2,583 \\
\hline \multirow{2}{*}{$\begin{array}{l}\text { Cash flow } \\
\text { to capital }\end{array}$} & $C F_{i t-1}$ & Dairy & 2263 & 0,1512 & 0,133 & $-0,165$ & 1,133 \\
\hline & $\overline{K_{i t-1}}$ & Crop & 1762 & 0,1617 & 0,142 & $-0,308$ & 0,924 \\
\hline \multirow{2}{*}{$\begin{array}{l}\text { Investment } \\
\text { subsidy to } \\
\text { capital }\end{array}$} & $I S_{i t-1}$ & Dairy & 2263 & 0,0200 & 0,081 & 0 & 1,231 \\
\hline & $\overline{K_{i t-1}}$ & Crop & 1762 & 0,0359 & 0,117 & 0 & 1,422 \\
\hline
\end{tabular}

\section{Results and Discussion}

\subsection{Here we present the results of estimating equations (1) and (2) of the FE and RE models}

Results of the Hausman test suggest using fixed effect models for dairy farms. The standard augmented accelerator model confirms a positive association between farm investment and real sale growth and cash flow variables respectively (Table 2). Our econometric results reject the validity of the soft budget constrains for dairy farms. Farm investments are positively associated with investment subsidies in time $t$. So, current investment subsidies are important for investment decisions. The results are similar by these two groups of farms. For both types of farms gross farm investment is positively and non - significantly associated with real sale growth and cash flow in the current period $t$ (Table 2).

Gross farm investment is positively, high and significantly associated with real sale growth in the current period $t$ for both groups of farms. For dairy farms, the regression coefficients for cash flow variables, irrespective to the model specification, are of a positive sign and non - significant implying an absence of soft budget constraint but a presence of capital market imperfections. We can see that for crop farms regression coefficients for cash flow variables are small and non significant an absence.

The regression coefficients for the investment subsidy variables are same for both types of farms: a positive sign, significant when pertaining to investment subsidy at time $t$. The regression coefficients for the lagged investment subsidy variables imply different long-term investment behavior of farms. 
Econometric results for both types of farms

\begin{tabular}{|c|c|c|c|c|}
\hline & \multicolumn{2}{|c|}{ Crop } & \multicolumn{2}{|c|}{ Dairy } \\
\hline & Eq.(2) & Eq.(1) & Eq.(2) & Eq.(1) \\
\hline Sale growth & $0,377199^{* * *}$ & $0,506837^{* * *}$ & $0,382652^{* * *}$ & $0,427059^{* * *}$ \\
\hline Cash flow & 0,046181 & 0,069505 & 0,071044 & $0,136091^{*}$ \\
\hline Investment subsidy & $1,799973^{* * *}$ & - & $2,000404^{* * *}$ & - \\
\hline $\mathrm{N}$ & 1762 & 1762 & 2263 & 2263 \\
\hline$R^{2}$ & 0,57033 & 0,14891 & 0,39664 & 0,10489 \\
\hline Hausman test ( $\mathrm{p}$-value) & 0,000 & 0,000 & 0,000 & 0,000 \\
\hline
\end{tabular}

Dependent variable: gross investment to capital. All explanatory variables are divided by capital. $\mathrm{N}-$ number observation. ${ }^{* *},{ }^{* *},{ }^{*}-$ statistically significant, respectively at the $1 \%, 5 \%, 10 \%$.

In the constructed model, investment subsidies are accompanied by a reduction in volumes of sales of agricultural products and, as a result, a decrease in cash flows, which leads to a reduction in credit resources for firms. But these conditions have a positive effect on the growth of investments in this industry (a higher coefficient of determination for models with subsidies) (this is probably due to an increase in the reliability of investments due to state support for this sector of the economy). Therefore, it is very important to determine the optimal amount of investment subsidies, since its excessive value can lead to a food crisis due to a decrease in agricultural sales and the inability of companies to borrow funds on their own due to a reduction in cash flows. A deficiency of investment subsidies hinders the development of this industry, slows down the investment process. Perhaps it makes sense to introduce obligations for firms to comply with the minimum volume of output while increasing subsidies; this will avoid the food crisis.

Table 3.

Econometric results for different types of milk farms

(big - middle - small)

\begin{tabular}{l|r|r|r|r|r|r}
\hline \multirow{2}{*}{ Dairy farms } & \multicolumn{2}{c|}{ Big } & \multicolumn{2}{c|}{ Middle } & \multicolumn{2}{c}{ Small } \\
\cline { 2 - 7 } & \multicolumn{1}{|c|}{ Eq.(1) } & Eq.(2) & Eq.(1) & Eq.(2) & Eq.(1) & Eq.(2) \\
\hline Sale growth & $0,347^{* * *}$ & $0,350^{* * *}$ & $0,324^{* * *}$ & $0,297^{* * *}$ & $0,578^{* * *}$ & $0,446^{* * *}$ \\
Cash flow & 0,060 & 0,210 & $0,255^{*}$ & 0,133 & $0,126^{*}$ & 0,019 \\
Investment subsidy & - & $2,134^{* * *}$ & - & $1,550^{* * *}$ & - & $2,124^{* * *}$ \\
$\mathrm{~N}$ & 545 & 545 & 338 & 338 & 1380 & 1380 \\
$R^{2}$ & 0,092 & 0,449 & 0,074 & 0,376 & 0,136 & 0,382 \\
Hausman test (p-value) & 0,000 & 0,000 & 0,002435 & 0,000 & 0,000 & 0,000 \\
\hline \hline
\end{tabular}

Dependent variable: gross investment to capital. All explanatory variables are divided by capital. N number observation. ${ }^{* * *},{ }^{* *},{ }^{*}-$ statistically significant, respectively at the $1 \%, 5 \%, 10 \%$. 
Table 3 presents the results for the types of dairy farms - large, medium and small. Analyzing the results of Table 3, we can notice that for large farms, the coefficients for all variables of the model (Eq.(2) - with subsidies) are higher than in the model (Eq.(1) - without subsidies). Coefficient $R^{2}=0,45$ for the second model, for the first model $R^{2}=0,09$. For medium-sized dairy farms the coefficients at the variables are almost the same, but the coefficient of determination is higher for the model with subsidies. For small farms, we can say the same thing. In addition, for Eq.(1) for medium and small farms, the coefficients for cash flow turned out to be significant. Significance is shown everywhere by asterisks next to the coefficient. If one asterisk, then the significance level is 0,1 , if two - then 0,01 ; if three, then 0,001 .

Table 4 presents the results for grain farms. For large farms, the coefficient for cash flow turned out to be negative in the case of the model without subsidies, for medium farms it is very small - close to zero, for small farms it is worse than for the model with subsidies. If we compare the coefficients for Eq.(1) - without subsidies and Eq.(2) - with subsidies, then according to the results of Table 4 it can be said that financing small and large grain farms is more justified than medium farms. A high level of significance of the coefficients at cash flow points to the increased impact of credit availability on gross investment in agriculture. This indicator directly depends on the size of the money supply, the speed of money turnover and it is difficult to regulate and unstable. All this indicates the difficulty of attracting investment in agriculture due to characteristics of the financial market of this economic system.

Table 4.

Econometric results for different of crop farms

(big - middle - small)

\begin{tabular}{l|r|r|r|r|r|r}
\hline \multirow{2}{*}{ Crop farms } & \multicolumn{2}{c|}{ Big } & \multicolumn{2}{c|}{ Middle } & \multicolumn{2}{c}{ Small } \\
\cline { 2 - 7 } & \multicolumn{1}{c|}{ Eq.(1) } & Eq.(2) & Eq.(1) & Eq.(2) & Eq.(1) & Eq.(2) \\
\hline Sale growth & $0,582^{* * *}$ & $0,432^{* * *}$ & $0,455^{* * *}$ & $0,376^{* * *}$ & $0,529^{* * *}$ & $0,306^{* * *}$ \\
Cash flow & $-0,028$ & 0,0247 & 0,0538 & $-0,007$ & 0,2416 & $0,256^{* *}$ \\
Investment subsidy & - & $1,838^{* * *}$ & - & $1,749^{* * *}$ & - & $1,856^{* * *}$ \\
$\mathrm{~N}$ & 483 & 483 & 889 & 889 & 390 & 390 \\
$R^{2}$ & 0,1599 & 0,704 & 0,121 & 0,465 & 0,219 & 0,630 \\
Hausman test (p-value) & 0,0001 & 0,000 & 0,0002 & 0,000 & 0,000 & 0,033 \\
\hline \hline
\end{tabular}

Dependent variable: gross investment to capital. All explanatory variables are divided by capital. N number observation. ${ }^{* * *},{ }^{* *},{ }^{*}-$ statistically significant, respectively at the $1 \%, 5 \%, 10 \%$.

Further, we divided the period under consideration for 15 years into three. And they looked at what period the financing was justified. The following tables 5-6 show the results of estimating econometric models (1) and (2) for three time periods: 2000-2004, 2005-2009, 2010-2014.

Results of the Hausman test suggest using fixed effect models for dairy and crop farms by time periods of 2005-2009 and 2010-2014. But for time period 2000-2004, according the Hausman test, we have to use random effect model for both types of farm. 
Econometric results for crop farms

Table 5.

(year)

\begin{tabular}{l|r|r|r|r|r|r}
\hline \multirow{2}{*}{ Crop farms } & \multicolumn{2}{|c|}{$2000-2004$} & \multicolumn{2}{c|}{$2005-2009$} & \multicolumn{2}{c}{$2010-2014$} \\
\cline { 2 - 7 } & Eq.(2) & Eq.(1) & Eq.(2) & Eq.(1) & Eq.(2) & Eq.(1) \\
\cline { 2 - 7 } & \multicolumn{1}{c}{ FE } & RE & FE & FE & FE & FE \\
\hline Intersept & \multicolumn{3}{c}{$-0,0257$} & & & \\
Sale growth & $0,3879^{* * *}$ & $0,404^{* * *}$ & $0,622^{* * *}$ & $0,572^{* * *}$ & $0,435^{* * *}$ & \multicolumn{1}{c}{$0,48^{* * *}$} \\
Cash flow & $0,6252^{*}$ & $1,19^{* *}$ & $-0,036^{* * *}$ & $0,319^{* * *}$ & $0,101^{* * *}$ & \multicolumn{1}{c}{$-0,059^{* * *}$} \\
Investment subsidy & $1,7614^{* * *}$ & - & $1,64^{* * *}$ & - & $1,77^{* * *}$ & - \\
N & 472 & 472 & 600 & 600 & 690 & 690 \\
$R^{2}$ & 0,725 & 0,153 & 0,3829 & 0,184 & 0,423 & 0,13145 \\
Hausman test (p-value) & 0,000 & 0,000 & 0,000 & 0,002556 & 0,000588 & 0,000 \\
\hline \hline
\end{tabular}

Dependent variable: gross investment to capital. All explanatory variables are divided by capital. $N$ number observation. ${ }^{* * *},{ }^{* *},{ }^{*}$ - statistically significant, respectively at the $1 \%, 5 \%, 10 \%$.

From 2005-2009, the cash flow ratio is negative for the model with subsidies.

Table 6.

Econometric results for dairy farms

(year)

\begin{tabular}{|c|c|c|c|c|c|c|}
\hline \multirow[t]{3}{*}{ Dairy farms } & \multicolumn{2}{|c|}{$2000-2004$} & \multicolumn{2}{|c|}{$2005-2009$} & \multicolumn{2}{|c|}{$2010-2014$} \\
\hline & Eq.(2) & Eq.(1) & Eq.(2) & Eq.(1) & Eq.(2) & Eq.(1) \\
\hline & $\mathrm{FE}$ & $\mathrm{RE}$ & $\mathrm{FE}$ & $\mathrm{FE}$ & $\mathrm{FE}$ & $\mathrm{FE}$ \\
\hline Intersept & & $-0,041598$ & & & & \\
\hline Sale growth & $0,2439^{* * *}$ & $0,1944^{* * *}$ & $1,1024^{* * *}$ & $1,133^{* * *}$ & $0,579^{* * *}$ & $0,4815^{* * *}$ \\
\hline Cash flow & $\begin{array}{c}0,487 \\
(p=0,056)\end{array}$ & $1,044529^{* * *}$ & $-0,03637$ & 0,019578 & 0,078748 & $-0,050476$ \\
\hline Investment subsidy & $2,3513^{* * *}$ & - & $1,2253^{* * *}$ & - & $2,013^{* * *}$ & - \\
\hline $\mathrm{N}$ & 743 & 743 & 790 & 790 & 730 & 730 \\
\hline$R^{2}$ & 0,493 & 0,114 & 0,309 & 0,242 & 0,538 & 0,0528 \\
\hline Hausman test (p-value) & 0,0186 & & 0,000 & 0,000 & 0,000 & 0,01017 \\
\hline
\end{tabular}

Dependent variable: gross investment to capital. All explanatory variables are divided by capital. $\mathrm{N}$ number observation. ${ }^{* * *},{ }^{* *},{ }^{*}-$ statistically significant, respectively at the $1 \%, 5 \%, 10 \%$. 
Table 6 presents the results for three periods for dairy farms. The picture is almost the same. Models with subsidies are better for the first and third time periods, but for 2005-2009 the model without subsidies is better.

These results clearly imply that the FADN farm investment behavior are driven by competitive output market conditions and the farm abilities to sell output and invest in such a market environment. Moreover, except for all farms farm gross investment is positively and significantly associated with cash flow, confirming for any farms the absence of the soft budget constraints for the FADN farms. For both type of farms the regression coefficients for the cash flow variables are insignificant. However, for both type of farms the regression coefficients for the cash flow variables are non-significant, including the coefficients on cash flow variable.

\subsection{Estimation of models by a generalized method of moments with using instrumental variables}

Since we are dealing with so-called cross-sectional data - data - some data are missing, we will evaluate the model in the first differences in a different way, and will compare the results. Annex 1 contains the results of estimating the equation in the first differences by a generalized method of moments using instrumental variables the comparison of econometric results for both types of farms.

\subsection{Comparison results of estimation by different ways: within and GMM with using of instrumental variables}

The regression results are reported in Table 7 and 8 . In the column «FE» we report the result estimation of Eq.(1) and Eq. (2) by fixed effect model for all dairy farms and for all crop farms. In the column «GMM» we report the result estimation of Eq.(3) and (4) in the first differences with the GMM technique using instrumental variables. All variables are instrumented using all available moment restrictions from $t-2$ and before. All equations include year dummies. The Sargan test is $\chi^{2}$ distributed, $p$-values are reported, $p$-values below 0,05 would suggest a rejection of the validity of the instruments at the $5 \%$ critical level.

The coefficients on the cash flow take different values for the different farms in our sample. For dairy farms we find a coefficient of 0,23 that is statistically significant and compares to a coefficient of 0,09 for crop farms. But this is observed only when estimating one Eq.(4). In all other cases we have an insignificant coefficient for cash flow. Thus, all farms seem to be credit constrained, a result is often observed in western market economies as well.

Finally, as a robustness check of the sensitivity of our results to outliers, we have reestimated every type of farm regression. The results are presented in the Annex 1 (Table A1-A4) and show to be qualitatively the same as the results for the full sample. 
Comparison of econometric results for all dairy farms

Table 7.

\begin{tabular}{l|r|r|r|r}
\hline \multirow{2}{*}{ Dairy farms } & \multicolumn{2}{c|}{ FE } & \multicolumn{2}{c}{ GMM (IV) } \\
\cline { 2 - 5 } & \multicolumn{1}{c|}{ Eq.(2) } & Eq.(1) & Eq.(4) & Eq.(3) \\
\hline Sale growth & $0,382652^{* * *}$ & $0,427059^{* * *}$ & $0,611619^{* * *}$ & $0,830625^{* * *}$ \\
Cash flow & 0,071044 & $0,136091^{*}$ & $0,235441^{* *}$ & 0,015042 \\
Investment subsidy & $2,000404^{* * *}$ & - & $1,858601^{* * *}$ & - \\
$\mathrm{N}$ & 2263 & 2263 & 2263 & 2263 \\
$R^{2}$ & 0,39664 & 0,10489 & & 101,534 \\
Hausman test (p-value) & 0,000 & 0,000 & & \\
Sargan Test & & & 83,18817 & (p-value $=0,322)$ \\
\end{tabular}

Dependent variable: gross investment to capital. All explanatory variables are divided by capital. $\mathrm{N}-$ number observation. ${ }^{* * *},{ }^{* *},{ }^{*}-$ statistically significant, respectively at the $1 \%, 5 \%, 10 \%$.

Table 8.

Comparison of econometric results for all crop farms

\begin{tabular}{l|r|r|r|r}
\hline \multirow{2}{*}{ Crop farms } & \multicolumn{2}{c|}{ FE } & \multicolumn{2}{c}{ GMM (IV) } \\
\cline { 2 - 5 } & \multicolumn{1}{c|}{ Eq.(2) } & Eq.(1) & Eq.(4) & Eq.(3) \\
\hline Sale growth & $0,377199^{* * *}$ & $0,506837^{* * *}$ & $0,437278^{* * *}$ & $0,594425^{* * *}$ \\
Cash flow & 0,046181 & 0,069505 & $0,313918^{* * *}$ & 0,092462 \\
Investment subsidy & $1,799973^{* * *}$ & - & $1,842398^{* * *}$ & - \\
$\mathrm{N}$ & 1762 & 1762 & 1762 & 1762 \\
$R^{2}$ & 0,57033 & 0,14891 & & \\
Hausman test (p-value) & 0,000 & 0,000 & & 91,8444 \\
Sargan Test & & & (p-value $=0,13532)(\mathrm{p}-\mathrm{value}=0,13102)$ \\
\hline \hline
\end{tabular}

Dependent variable: gross investment to capital. All explanatory variables are divided by capital. $\mathrm{N}-$ number observation. ${ }^{* *},{ }^{* *},{ }^{*}-$ statistically significant, respectively at the $1 \%, 5 \%, 10 \%$. 


\section{Concluding Remarks}

In this paper we analyzed the linkages between financial and investment behavior of Estonian farms. For this purpose we used an adapted augmented accelerator model of gross farm investment for a panel data of Estonia FADN farms to investigate the impact of real sale growth, cash flow and investment subsidy on gross farm investment, during the period 2000-2014, which has been econometrically estimated. The empirical results confirmed the presence of capital market imperfections for the dairy farm investments, particularly for small farms, which are prevailing in the Estonian farming structures. Since these farms, due to insignificant volumes of production, do not have the opportunity to save on the scale of production, their profit is lower than the average in the industry, and therefore they simultaneously have an increased need for borrowed funds and a low solvency on the loan. For crop farms the results showed that big farms were financially constrained more than middle and small farms. Also, our results confirm credit rationing in 2000-2004 in case of smaller farms. In 2010-2014 there were no evidence of soft budget constraints.

In conditions when the soft budget constraints are not aimed at stimulating the investment activity of producers, their size should ensure the production of such volumes of agricultural products that guarantee the food security of the state. This is due to the fact that in the condition of the economic crisis, when the volume of production in all sectors of the economy is small, this can lead to problems with ensuring the food security of the population, which is reflected in a decrease in the level of the food security of the state. Therefore, when the firms are not interested in investing the agriculture, it is necessary to maintain a fixed volume of output sufficient to ensure the food security. And this is possible when pursuing a policy of soft budget constraints which provides a better access to credit funds for all agricultural companies regardless of their profitability, which is especially good in a crisis.

Annex 1.

Table A1.

GMM estimations for all dairy farms

\begin{tabular}{|c|c|c|}
\hline Coefficients & Eq.(4). & Eq.(3) \\
\hline$Q_{i t}$ & $0,611619^{* * *}$ & $0,830625^{* * *}$ \\
\hline$\overline{K_{i t-1}}$ & $(0,082902)$ & $(0,125162)$ \\
\hline$C F_{i t-1}$ & $0,235441^{* *}$ & 0,015042 \\
\hline$\overline{K_{i t-1}}$ & $(0,081197)$ & $(0,141133)$ \\
\hline$I S_{i t-1}$ & $1,858601^{* * *}$ & 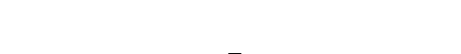 \\
\hline$\overline{K_{i t-1}}$ & $(0,151493)$ & - \\
\hline $\mathrm{N}$ & 2263 & 2263 \\
\hline Sargan Test: & $83,188(p$-value $=0,322)$ & $101,534(\mathrm{p}$-value $=0,0379)$ \\
\hline Autocorrelation test (1) & $-3,621(p-$ value $=0,0002)$ & $-4,3996(p$-value $=1,0844 \mathrm{e}-05)$ \\
\hline Autocorrelation test (2) & $-0,0329(p-$ value $=0,974)$ & $0,99680(p-$ value $=0,3188)$ \\
\hline Wald test for coefficients & 220,57 (p-value = 2,22e-16) & $44,787(\mathrm{p}-$ value $=1,8818 \mathrm{e}-10)$ \\
\hline Wald test for time dummies & $67,931(\mathrm{p}$-value $=7,799 \mathrm{e}-10)$ & $48,98277(\mathrm{p}$-value $=2,1062 \mathrm{e}-06)$ \\
\hline
\end{tabular}


GMM estimations for all crop farms

\begin{tabular}{|c|c|c|}
\hline Coefficients & Eq.(4) & Eq.(3) \\
\hline$Q_{i t}$ & $0,437278^{* * *}$ & $0,594425^{* * *}$ \\
\hline$\overline{K_{i t-1}}$ & $(0,088326)$ & $(0,109361)$ \\
\hline$C F_{i t-1}$ & $0,313918^{* * *}$ & 0,092462 \\
\hline$\overline{K_{i t-1}}$ & $(0,076581)$ & $(0,112390)$ \\
\hline$I S_{i t-1}$ & $1,842398^{* * *}$ & - \\
\hline$\overline{K_{i t-1}}$ & $(0,071187)$ & \\
\hline $\mathrm{N}$ & 1762 & 1762 \\
\hline Sargan Test: & $91,84443(p-$ value $=0,13532)$ & $92,1235(\mathrm{p}$-value $=0,13102)$ \\
\hline Autocorrelation test (1) & $-6,4622(p-$ value $=1,0315 e-10)$ & $-6,636188(p-$ value $=3,219 e-11)$ \\
\hline Autocorrelation test (2) & $-0,4857468(p-$ value $=0,62715)$ & $-0,3679207$ (p-value = 0,71293) \\
\hline Wald test for coefficients & $721,65(\mathrm{p}-$ value $=2,22 \mathrm{e}-16)$ & $30,51489(\mathrm{p}-$ value $=2,3647 \mathrm{e}-07)$ \\
\hline Wald test for time dummies & $92,54612(p-$ value $=1,5841 \mathrm{e}-14)$ & $74,05891(\mathrm{p}$-value $=5,5321 \mathrm{e}-11)$ \\
\hline
\end{tabular}

GMM estimations for big - middle - small dairy farms

Table A3.

\begin{tabular}{|c|c|c|c|c|c|c|}
\hline \multirow[t]{2}{*}{ Coefficients } & \multicolumn{3}{|c|}{ Eq.(3) } & \multicolumn{3}{|c|}{ Eq.(4) } \\
\hline & Big & Middle & Small & Big & Middle & Small \\
\hline$\frac{Q_{i t}}{K_{i t-1}}$ & $\begin{array}{l}0,701^{* * *} \\
(0,143)\end{array}$ & $\begin{array}{l}0,538^{* *} \\
(0,204)\end{array}$ & $\begin{array}{l}0,994^{* * *} \\
(0,201)\end{array}$ & $\begin{array}{c}0,5428^{* * *} \\
(0,13887)\end{array}$ & $\begin{array}{c}0,469^{*} \\
(0,1944)\end{array}$ & $\begin{array}{l}0,7479^{* * *} \\
(0,1384)\end{array}$ \\
\hline$\frac{C F_{i t-1}}{K_{i t-1}}$ & $\begin{array}{l}-0,175 \\
(0,285)\end{array}$ & $\begin{array}{c}0,276 \\
(0,259)\end{array}$ & $\begin{array}{c}0,076 \\
(0,163)\end{array}$ & $\begin{array}{c}0,26341^{*} \\
(0,12811)\end{array}$ & $\begin{array}{c}0,2426 \\
(0,2423)\end{array}$ & $\begin{array}{c}0,279^{*} \\
(0,113)\end{array}$ \\
\hline$\frac{I S_{i t-1}}{K_{i t-1}}$ & - & - & - & $\begin{array}{l}2,15603^{* * *} \\
(0,23850)\end{array}$ & $\begin{array}{c}1,422^{* * *} \\
(0,2316)\end{array}$ & $\begin{array}{c}1,874^{* * *} \\
(0,19)\end{array}$ \\
\hline $\mathrm{N}$ & 545 & 338 & 1380 & 545 & 338 & 1380 \\
\hline Sargan Test: & $\begin{array}{c}38,136 \\
(p-\text { value }= \\
0,99)\end{array}$ & $\begin{array}{c}21,51685 \\
(p-\text { value = 1) }\end{array}$ & $\begin{array}{c}78,24 \\
\text { (p-value }= \\
0,47)\end{array}$ & $\begin{array}{c}47,70259 \\
\text { (p-value }= \\
0,997)\end{array}$ & $\begin{array}{c}24,37368 \\
(p-\text { value }=1)\end{array}$ & $\begin{array}{c}86,278 \\
\text { (p-value }= \\
0,24)\end{array}$ \\
\hline $\begin{array}{l}\text { Autocorrelation } \\
\text { test (1) }\end{array}$ & $\begin{array}{c}-2,682 \\
(p-\text { value }= \\
0,007)\end{array}$ & $\begin{array}{c}-2,568 \\
(p-\text { value }= \\
0,010)\end{array}$ & $\begin{array}{c}-2,897 \\
(p-\text { value }= \\
0,004)\end{array}$ & $\begin{array}{c}-3,321 \\
(\mathrm{p}-\text {-value }= \\
0,0008)\end{array}$ & $\begin{array}{c}-1,746 \\
(p-\text { value }= \\
0,0807)\end{array}$ & $\begin{array}{c}-2,5549 \\
\text { (p-value }= \\
0,010)\end{array}$ \\
\hline
\end{tabular}


Continues

\begin{tabular}{|c|c|c|c|c|c|c|}
\hline \multirow[t]{2}{*}{ Coefficients } & \multicolumn{3}{|c|}{ Eq.(3) } & \multicolumn{3}{|c|}{ Eq.(4) } \\
\hline & Big & Middle & Small & Big & Middle & Small \\
\hline $\begin{array}{l}\text { Autocorrelation } \\
\text { test (2) }\end{array}$ & $\begin{array}{c}0,714 \\
(p-\text { value }= \\
0,475)\end{array}$ & $\begin{array}{c}0,595179 \\
\text { (p-value = } \\
0,5517)\end{array}$ & $\begin{array}{c}-0,0433 \\
\text { (p-value }= \\
0,965)\end{array}$ & $\begin{array}{c}-1,10959 \\
(p-\text { value }= \\
0,267)\end{array}$ & $\begin{array}{c}0,3932578 \\
(p-\text { value = } \\
0,69413)\end{array}$ & $\begin{array}{c}-0,2327 \\
\text { (p-value = } \\
0,81613)\end{array}$ \\
\hline $\begin{array}{l}\text { Wald test } \\
\text { for coefficients }\end{array}$ & $\begin{array}{c}24,60 \\
(p-\text { value = } \\
4,55 e-06)\end{array}$ & $\begin{array}{c}7,7412 \\
\text { (p-value }= \\
0,0208)\end{array}$ & $\begin{array}{c}24,48 \\
(p-\text { value }= \\
4,8 \mathrm{e}-06)\end{array}$ & $\begin{array}{l}116,9879 \\
(p-\text { value }= \\
2,22 e-16)\end{array}$ & $\begin{array}{l}85,51565 \\
\text { (p-value = } \\
2,22 \mathrm{e}-16)\end{array}$ & $\begin{array}{c}150,699 \\
\text { (p-value = } \\
2,22 \mathrm{e}-16)\end{array}$ \\
\hline $\begin{array}{l}\text { Wald test for } \\
\text { time dummies }\end{array}$ & $\begin{array}{c}110,82 \\
(p-\text { value }= \\
2,22 \mathrm{e}-16)\end{array}$ & $\begin{array}{c}54,075 \\
\text { (p-value = } \\
2,64 \mathrm{e}-07)\end{array}$ & $\begin{array}{c}\text { chisq }(12)= \\
24,13 \\
(p-\text {-value }= \\
0,02)\end{array}$ & $\begin{array}{c}53,724 \\
(p-\text { value = } \\
3,06 e-07)\end{array}$ & $\begin{array}{c}51,031 \\
\text { (p-value = } \\
9,19 \mathrm{e}-07)\end{array}$ & $\begin{array}{c}35,59898 \\
(p-\text { value }= \\
0,0004)\end{array}$ \\
\hline
\end{tabular}

GMM estimations for big - middle - small crop farms

\begin{tabular}{|c|c|c|c|c|c|c|}
\hline \multirow[t]{2}{*}{ Coefficients } & \multicolumn{3}{|c|}{ Eq.(3) } & \multicolumn{3}{|c|}{ Eq.(4) } \\
\hline & Big & Middle & Small & Big & Middle & Small \\
\hline$\frac{Q_{i t}}{K_{i t-1}}$ & $\begin{array}{c}0,6401^{* * *} \\
(0,153)\end{array}$ & $\begin{array}{c}0,682^{* * *} \\
(0,13)\end{array}$ & $\begin{array}{l}0,692^{*} \\
(0,301)\end{array}$ & $\begin{array}{c}0,445^{* * *} \\
(0,1167)\end{array}$ & $\begin{array}{l}0,5432^{* * *} \\
(0,1284)\end{array}$ & $\begin{array}{l}0,354^{* *} \\
(0,136)\end{array}$ \\
\hline$\frac{C F_{i t-1}}{K_{i t-1}}$ & $\begin{array}{l}0,20164 \\
(0,154)\end{array}$ & $\begin{array}{c}0,0479 \\
(0,1419)\end{array}$ & $\begin{array}{l}-0,130 \\
(0,363)\end{array}$ & $\begin{array}{c}0,167 \\
(0,12862)\end{array}$ & $\begin{array}{l}0,2746^{*} \\
(0,108)\end{array}$ & $\begin{array}{c}0,396^{*} \\
(0,155)\end{array}$ \\
\hline$\frac{I S_{i t-1}}{K_{i t-1}}$ & - & - & - & $\begin{array}{c}1,897^{* * *} \\
(0,0583)\end{array}$ & $\begin{array}{c}1,739^{* * *} \\
(0,11424)\end{array}$ & $\begin{array}{c}1,889^{* * *} \\
(0,12)\end{array}$ \\
\hline $\mathrm{N}$ & 483 & 889 & 390 & 483 & 889 & 390 \\
\hline Sargan Test: & $\begin{array}{c}30,9 \\
(p-\text { value = 1) }\end{array}$ & $\begin{array}{c}70,184 \\
(p-\text { value }= \\
0,72)\end{array}$ & $\begin{array}{c}26,978 \\
(p-\text { value }=1)\end{array}$ & $\begin{array}{c}35,51 \\
(p-\text { value }= \\
0,999)\end{array}$ & $\begin{array}{c}69,592 \\
(p-\text { value }= \\
0,74)\end{array}$ & $\begin{array}{c}21,65 \\
(p-\text { value }=1)\end{array}$ \\
\hline $\begin{array}{l}\text { Autocorrelation } \\
\text { test (1) }\end{array}$ & $\begin{array}{c}-3,79 \\
(\mathrm{p}-\text { value }= \\
0,0001)\end{array}$ & $\begin{array}{c}-5,402 \\
(p-\text { value }= \\
6,5812 \mathrm{e}-08)\end{array}$ & $\begin{array}{c}-1,9523 \\
(p-\text { value }= \\
0,05)\end{array}$ & $\begin{array}{c}-3,545267 \\
(p-\text { value }= \\
0,0003)\end{array}$ & $\begin{array}{c}-5,080609 \\
(p-\text { value }= \\
3,7623 e-07)\end{array}$ & $\begin{array}{c}-2,465 \\
(p-\text { value }= \\
0,0136)\end{array}$ \\
\hline $\begin{array}{l}\text { Autocorrelation } \\
\text { test (2) }\end{array}$ & $\begin{array}{c}-0,275 \\
(\mathrm{p}-\text { value }= \\
0,7832)\end{array}$ & $\begin{array}{c}-0,224 \\
(p-\text { value }= \\
0,82)\end{array}$ & $\begin{array}{c}0,344 \\
(p-\text { value }= \\
0,73)\end{array}$ & $\begin{array}{c}0,1519 \\
(p-\text { value }= \\
0,87926)\end{array}$ & $\begin{array}{c}-0,3515(\mathrm{p}- \\
\text { value = } \\
0,72517)\end{array}$ & $\begin{array}{c}0,074 \\
(\mathrm{p} \text {-value }= \\
0,94073)\end{array}$ \\
\hline
\end{tabular}




\begin{tabular}{|c|c|c|c|c|c|c|}
\hline \multirow[t]{2}{*}{ Coefficients } & \multicolumn{3}{|c|}{ Eq.(3) } & \multicolumn{3}{|c|}{ Eq. (4) } \\
\hline & Big & Middle & Small & Big & Middle & Small \\
\hline $\begin{array}{l}\text { Wald test } \\
\text { for coefficients }\end{array}$ & $\begin{array}{c}17,678 \\
(p-\text { value }= \\
0,00014)\end{array}$ & $\begin{array}{c}27,028 \\
(p-\text { value }= \\
1,3517 \mathrm{e}-06)\end{array}$ & $\begin{array}{c}6,29456 \\
(\mathrm{p} \text {-value }= \\
0,04)\end{array}$ & $\begin{array}{l}1218,491 \\
\text { (p-value= } \\
2,22 \mathrm{e}-16)\end{array}$ & $\begin{array}{l}358,1614 \\
\text { (p-value= } \\
2,22 \mathrm{e}-16)\end{array}$ & $\begin{array}{l}285,5127 \\
\text { (p-value= } \\
2,22 \mathrm{e}-16)\end{array}$ \\
\hline $\begin{array}{l}\text { Wald test for } \\
\text { time dummies }\end{array}$ & $\begin{array}{c}60,54 \\
\text { (p-value = } \\
1,79 e-08)\end{array}$ & $\begin{array}{c}45,31168 \\
\text { (p-value = } \\
9,11 e-06)\end{array}$ & $\begin{array}{c}22,8897 \\
(p-\text { value }= \\
0,02)\end{array}$ & $\begin{array}{c}29,64912 \\
(p-\text { value }= \\
0,00315)\end{array}$ & $\begin{array}{c}61,73823 \\
\text { (p-value }= \\
1,08 \mathrm{e}-08)\end{array}$ & $\begin{array}{c}13,72419 \\
(p-\text { value }= \\
0,32)\end{array}$ \\
\hline
\end{tabular}

Standard errors in brackets, $\frac{Q_{i t}}{K_{i t-1}}, \frac{C F_{i t-1}}{K_{i t-1}}$ and $\frac{I S_{i t-1}}{K_{i t-1}}$ are instrumented using all available moment restrictions from $t-2$ and before. All equations include year dummies. The Sargan test is $\chi^{2}$ distributed, pvalues are reported, $\mathrm{p}$-values below 0,05 would suggest a rejection of the validity of the instruments at the $5 \%$ critical level. Autocorrelation test follows a Normal distribution.

\section{References}

Arellano M., Bond S. (1991) Some Tests of Specification for Panel Data: Monte Carlo Evidence and an Application to Employment Equations. Review of Economic Studies, 58, pp. 277-297.

Bakucs L.Z., Fertö I., Fogarasi J. (2009) Investment and Financial Constraints in Hungarian Agriculture. Economics Letters, 104, pp. 122-124.

Bakucs L.Z., Fertö I., Bojnec S., Latruffe L. (2011) Investment and Financial Constraints in European agriculture: Evidence from France, Hungary and Slovenia. Paper prepared for presentation at the EAAE 2011 Congress Change and Uncertainty «Challenges for Agriculture, Food and Natural Resources»: Zurich, Switzerland, Aug. 30 - Sept. 2

Bojnec S.., Latruffe L. (2007) Investment of Slovenian Farms in the Transition Context. Agricultural Economics and Transition: "What Was Expected, What We Observed, the Lessons Learned». EAAE Seminar. Budapest: Corvinus University.

Budina N., Garretsen H., de Jong E. (2000) Liquidity Constraints and Investment in Transition Economies: The Case of Bulgaria. Economics of Transition, 8, pp. 453-475.

Estonian Ministry of Agriculture (1999) Agriculture and Rural Life. Overview 1998. Tallinn.

Fazzari S.M., Hubbard R.G., Petersen B.C. (1988) Financing Constraints and Corporate Investment. Brooking Papers on Economic Activity, 19, 1, pp. 141-206.

Gilchrist S., Zakraj`sek E. (2012) Credit Supply Shocks and Economic Activity in a Financial Accelerator Model. Paper presented at the joint conference «Rethinking Finance: Perspectives on the Crisis», organized by the Russell Sage Foundation and The Century Foundation, New York, April 13.

Konings J., Rizov M., Vandebussche H. (2003) Investment and Financial Constraints in Transition Economies: Micro Evidence from Poland, the Czech Republic, Bulgaria and Romania. Economics Letters, 78, pp. 253-258. 
Latruffe L. (2005) The Impact of Credit Market Imperfections on Farm Investment in Poland. PostCommunist Economies, 17, 3, pp. 351-362.

Latruffe L., Davidova S., Douarin E., Gorton M. (2010) Farm Expansion in Lithuania after Accession to the EU: The Role of CAP Payments in Alleviating Potential Credit Constraints. Europe-Asia Studies, 62, 2, pp. 351-365.

Lizal L., Svejnar J. (2002) Investment, Credit Rationing and Soft Budget Constraint: Evidence from Czech Panel Data. The Review of Economics and Statistics, 84, 2, pp. 353-370.

Petrick M. (2004) Farm Investment, Credit Rationing, and Governmentally Promoted Credit Access in Poland. A Cross-sectional Analysis. Food Policy, 29, pp. 275-294.

Rizov M., Gavrilescu D., Gow H., Mathijs E., Swinnen J. (2001) Transition and Enterprise Restructuring: The Development of Individual Farming in Romania. World Development, 29, 7, pp. 1257-1274.

Rizov M. (2004a) Credit Constraints and Profitability: Evidence from Transition Economy. Emerging Markets Finance and Trade, 40, 4, pp. 63-83.

Rizov M. (2004b) Firm Investment in Transition. Evidence from Romanian Manufacturing. Economics of Transition, 12, 4, pp. 721-746.

Wooldridge J. (2013) Introductory Econometrics: A Modern Approach. $5^{\text {th }}$ ed. International Student Edition, Thomson South-Western, Mason, USA. 